\title{
Pengaruh Waktu Penyimpanan Ovarium Terhadap Kuantitas dan Kualitas Oosit serta Tingkat Maturasi Oosit secara In Vitro pada Sapi Simental
}

\section{Effect of Storage Time of Ovaries on the Quantity and Quality and In Vitro Maturation Rate Oocyte of Bovine}

\author{
N. Rahma*, Z. Udin, dan Masrizal \\ Fakultas Peternakan, Universitas Andalas, Padang - Indonesia \\ *Corresponding E-mail: nadiarahma979@gmail.com \\ (Diterima: 29 Juli 2020; Disetujui: 1 Oktober 2020)
}

\begin{abstract}
ABSTRAK
Penelitian ini bertujuan untuk mengetahui pengaruh waktu penyimpanan ovarium terhadap kuantitas dan kualitas oosit serta tingkat maturasi oosit secara in vitro. Ovarium yang digunakan berasal dari Rumah Potong Hewan (RPH) yang ada di kota Padang dan Payakumbuh. Data dianalisa dengan uji T. Penelitian terdiri dari 3 perlakuan, yaitu waktu penyimpanan selama 3 jam (P1), 6 jam (P2) dan 9 jam (P3). Hasil yang diperoleh menunjukkan waktu penyimpanan tidak memiliki pengaruh yang nyata $(\mathrm{P}>0.05)$ terhadap kuantitas oosit. Kuantitas oosit yang dihasilkan pada penyimpanan P1 adalah 463; P2 = 456, dan P3 = 449. Sedangkan untuk kualitas oosit P1, P2, dan P3 secara berturut-turut dengan morfologi grade $\mathrm{A}=$ $13,2 \% ; 21 \% ; 7,6 \%$, grade $\mathrm{B}=73 \% ; 53,5 \% ; 47,8 \%$, grade $\mathrm{C}=7,8 \% ; 14,5 \% ; 22,9 \%$, dan grade $\mathrm{D}=6 \%$; $11 \% ; 21,6 \%$. Untuk tingkat maturasi oosit dengan waktu penyimpanan P1, P2, dan P3 secara berturutturut adalah dengan status inti $\mathrm{GV}=22,1 \% ; 12,3 \% ; 26,5 \%, \mathrm{GVBD}=8,7 \% ; 15,9 \% ; 21,3 \%, \mathrm{M} 1=1,7 \%$; $11,5 \% ; 10,4 \%, \mathrm{~A} / \mathrm{T}=0 \% ; 0,3 \% ; 0 \%$, dan $\mathrm{M} 2=67,4 \% ; 60 \% ; 41,8 \%$. Waktu penyimpanan selama 3 jam memberikan kuantitas dan kualitas serta tingkat maturasi oosit secara in vitro terbaik dibandingkan dengan waktu penyimpanan selama 6 jam dan 9 jam.
\end{abstract}

Kata kunci: kualitas, oosit, maturasi, in vitro, penyimpanan ovarium, sapi

\section{ABSTRACT}

This study aims to determine the effect of storage time of the ovaries on the quantity and quality of oocytes and in vitro maturation rate oocyte of bovine. The ovaries used are derived from slaughterhouses (RPH) in Padang and Payakumbuh. The T-test analyzes data. The ovaries are grouped based on the storage time of $3 h(P 1), 6 h(P 2)$, and $9 h(P 3)$. The results indicate the storage time does not have a significant effect $(P>0.05)$ on the quantity of oocyte. The quantity of oocyte of storage time is $P 1=463 ; P 2=456$ dan $P 3=$ 449. As for the quality of oocyte P1, P2 and P3 successively with morphology grade $A=13.2 \% ; 21 \% ; 7.6 \%$, grade $B=73 \% ; 53.5 \% ; 47.8 \%$, grade $C=7.8 \% ; 14.5 \% ; 22.9 \%$ and grade $D=6 \% ; 11 \% ; 21.6 \%$. For invitro maturation rate with consecutive $P 1, P 2$, and $P 3$ of storage times have $G V=22.1 \% ; 12.3 \% ; 26.5 \%$, $G V B D=8.7 \% ; 15.9 \% ; 21.3 \%, M 1=1.7 \% ; 11.5 \% ; 10.4 \%, A / T=0 \% ; 0.3 \% ; 0 \%$ and $M 2=67.4 \% ; 60 \%$; $41.8 \%$. The storage time of $3 \mathrm{~h}$ provide quantity, quality, and in vitro maturation rate of the oocyte, bovine is better when compared with the storage time for $6 \mathrm{~h}$ and $9 \mathrm{~h}$.

Keywords: quality, oocyte, maturation, in vitro, storage time of ovaries, bovine

\section{PENDAHULUAN}

Peningkatan jumlah penduduk sejalan dengan peningkatan kebutuhan protein hewani terutama daging sapi di Indonesia.
Hal ini juga harus sejalan dengan peningkatan populasi sapi agar terjadi keseimbangan antara permintaan dan ketersediaan. Tingginya permintaan daging sapi mengakibatkan terjadinya peningkatan angka pemotongan 
sapi di Indonesia. Menurut Badan Pusat Statistik (2019) terjadi peningkatan angka pemotongan sapi di Indonesia pada tahun 2016 sebanyak 1.163 .459 ekor meningkat menjadi 1.429.202 ekor pada tahun 2018 . Dimana Direktorat Jendral Peternakan dan Kesehatan Hewan Kemenentrian Pertanian (2018) melaporkan bahwa sebesar 22.278 ekor sapi yang dipotong adalah sapi betina.

Tingkat pemotongan sapi berbanding lurus dengan hasil limbah yang dihasilkan di Rumah Potong Hewan (RPH). Menurut Febretrisiana dan Pamungkas (2017) mengatakan bahwa limbah yang dihasilkan dari RPH dapat dimanfaatkan sebagai sumber materi genetik sehingga dapat meningkatkan nilai gunanya. Salah satu langkah yang dapat dilakukan dalam memanfaatkan limbah dari RPH tersebut adalah dengan penerapan bioteknologi reproduksi PEIV (Produksi Embrio secara In Vitro).

PEIV merupakan salah satu bioteknologi reproduksi yang dilaporkan dapat meningkatkan populasi ternak (El-Raey and Nagai, 2014), mengatasi repeat breeding, dan sebagai upaya dalam menyelamatkan materi genetik hewan dengan memanfaatkan ovarium yang selama ini menjadi limbah dari Rumah Potong Hewan (RPH) sehingga dapat meningkatkan nilai gunanya (Hendri et al., 2004; Febretrisiana dan Pamungkas, 2017). Prinsip dari PEIV ini adalah pembuahan sel telur oleh spermatozoa di luar tubuh hewan betina yang direkayasa untuk memproduksi embrio dalam jumlah banyak (Vicanco and Mackie, 2001).

Salah satu komponen penting dalam prosedur pelaksanaan bioteknologi PEIV yaitu IVM (in vitro maturation). Beberapa hasil penelitian melaporkan bahwa tingkat keberhasilan bioteknologi PEIV dilaporkan masih rendah, salah satunya disebabkan oleh waktu penyimpanan ovarium selama dari RPH ke Laboratorium (Ikhwan et al., 2016). Wongsrikeao et al. (2005) melaporkan bahwa waktu transportasi ovarium babi dari RPH ke laboratorium selama 0-3 jam dengan persentase sebesar $74 \%$ menunjukkan persentase tingkat maturasi inti oosit mencapai M2 lebih tinggi dibandingkan dengan waktu transportasi selama 6 jam sebesar $48 \%$, waktu transportasi selama 9 jam sebesar $35 \%$. Kualitas oosit akan tetap terjaga apabila pengerjaan proses PEIV segera dilakukan setelah kematian hewan. Jarak antara laboratorium dengan RPH perlu diperhatikan karena akan mempengaruhi kualitas oosit dan angka keberhasilan dari komponen PEIV.

Penelitian ini dilakukan untuk mengetahui pengaruh waktu penyimpanan ovarium terhadap kuantitas dan kualitas oosit serta tingkat maturasi secara in vitro pada sapi simental.

\section{METODE}

\section{Transportasi Ovarium dari RPH ke Laboratorium}

Pelaksanaan penelitian ini dimulai dari transportasi ovarium dari RPH ke Laboratorium sesuai dengan waktu perlakuan penyimpanan (3 jam, 6 jam, dan 9 jam). Ovarium dibawa menggunakan media transportasi $(\mathrm{NaCl}$ fisiologis $0,9 \%+$ Penicilin $(100 \mathrm{IU} / \mathrm{ml})$ dan Streptomycin $(0,1 \mathrm{mg} /$ $\mathrm{mL}$ ) dan dijaga pada suhu $37^{\circ} \mathrm{C}$. Setelah di Laboratorium ovarium dikoleksi dengan metode slicing untuk mendapatkan oosit.

\section{Koleksi dan Evaluasi Oosit}

Setelah oosit dikoleksi, oosit dievaluasi dengan melakukan pengamatan menggunakan mikroskop stereo (Nikon SMZ660) untuk melihat kuantitas dan kualitas oosit (Gambar 1). Kualitas oosit dievaluasi berdasarkan sel kumulus yang mengelilingi oosit yang dikategorikan menurut menjadi 4 grade menurut Budiyanto et al. (2013) yaitu:

A: kategori paling baik yang ditandai dengan oosit dikelilingi lebih dari 5 lapisan sel kumulus yang kompak dan seragam, dan sitoplasma homogen;

B: Oosit dengan kategori baik, ditandai dengan oosit yang seragam dan memiliki sel kumulus kurang dari lima lapisan serta 


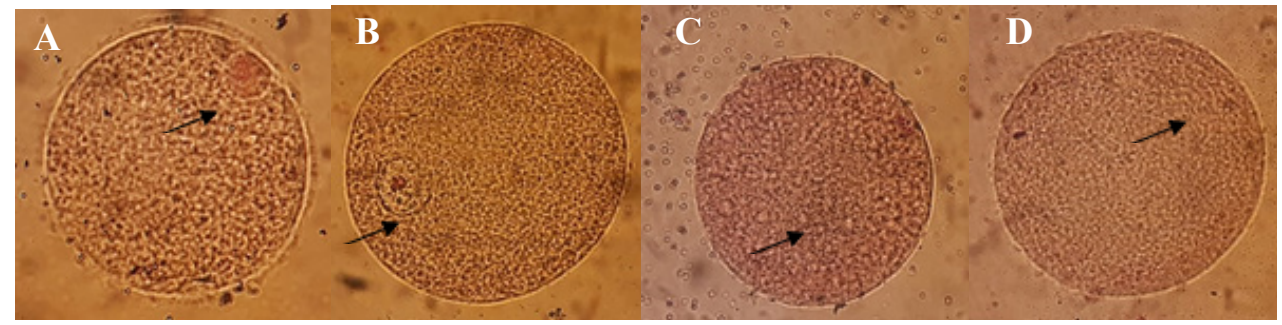

Gambar 1. Pengamatan kualitas oosit.

Keterangan: $\mathrm{A}=\mathrm{GV} ; \mathrm{B}=\mathrm{GVBD} ; \mathrm{C}=\mathrm{M} 1 ; \mathrm{D}=\mathrm{M} 2$

memiliki sitoplasma yang gelap.

C: Oosit dengan kategori kurang baik ditandai dengan oosit dikelilingi oleh sel kumulus yang tidak merata dan tidak kompak serta warna sitoplasma lebih transparan dan tidak merata.

D: Oosit dengan kategori paling buruk, ditandai dengan tidak adanya sel kumulus dan kondisi sitoplasma yang transparan.

\section{Maturasi Oosit secara In Vitro}

Hasil koleksi oosit (Grade A dan B) kemudian dicuci didalam media washing (TCM $199: 5.000 \mu \mathrm{L}, \mathrm{BSA}: 0.0150$ gram dan Penicilin (100 IU/ml) dan Streptomycin (0.1 $\mathrm{mg} / \mathrm{mL}) 5 \mu \mathrm{L}$ sebanyak 3 kali. Oosit kemudian di pindahkan dari medium maturasi, 1 drop berisikan $100 \mu \mathrm{L}$ medium maturasi (TCM 199 (Sigma USA), BSA (Bovine Serum Albumin) 0,3 \%, PMSG (Pregnant Mare Serum Gonadotropin), hCG (Human Chorionic Gonadotropin $10 \mu \mathrm{L}$ ), Penicilin $(100 \mathrm{IU} / \mathrm{ml})$ dan Streptomycin $(0,1 \mathrm{mg} /$ $\mathrm{mL)} 10 \mu \mathrm{L}$ ) untuk 10-15 oosit dan ditutup dengan mineral oil (Sigma USA). Kemudian di maturasi didalam inkubator selama 24 jam dengan suhu $38,5^{\circ} \mathrm{C}, \mathrm{CO}_{2} 5 \%$. Semua media yang digunakan dalam penelitian ini di inkubasi didalam inkubator suhu $38,5^{\circ} \mathrm{C}, \mathrm{CO}_{2}$ $5 \%$ selama 2 jam sebelum digunakan. Oosit yang telah dimaturasi kemudian dievaluasi tingkat kematangannya dengan cara di hilangkan sel kumulusnya (denudasi) dengan bantuan enzim hyaluronidase (Sigma USA) dan dipipet berulang-ulang. Hasil denudasi diletakkan di atas kaca preparat kemudian ditutup dengan cover glass yang memiliki bantalan paraffin dan vaselin (1:9) pada kedua sisinya. Kemudian di fiksasi di dalam larutan asam asetat dan etanol dengan perbandingan 1:3 selama 48 jam, setelah 48 jam dilakukan pewarnaan dengan arceto orcein $2 \%$ selama 5 menit dan dibilas dengan asam asetat $25 \%$. Status inti oosit diamati dengan menggunakan mikroskop fase kontras. Evaluasi tingkat kematangan inti oosit dinilai berdasarkan status inti oosit dari tahap GV (Germinal Vesicle) sampai M2 (Metaphase 2).

\section{HASIL DAN PEMBAHASAN}

\section{Kuantitas Oosit}

Kuantitas oosit yang dihasilkan selama waktu penyimpanan ovarium $\mathrm{P} 1=463$ oosit, $\mathrm{P} 2=456$ oosit, dan P3 $=449$ oosit (Tabel 1 ). Hal ini menunjukkan bahwa semakin cepat proses koleksi oosit dilaboratorium maka semakin banyak pula kuantitas oosit yang dihasilkan, akan tetapi hasil analisa statistik menunjukkan bahwa tidak terdapat pengaruh yang nyata $(\mathrm{P}>0,05)$ antara waktu penyimpanan ovarium terhadap kuantitas oosit. Ada beberapa faktor yang mempengaruhi kuantitas oosit, antara lain status reproduksi, umur, metode koleksi oosit, suhu media, dan kualitas folikel serta ukuran folikel (Udin et al., 2020; Gordon, 2003). Hasil penelitian ini juga didukung oleh hasil penelitian Udin et al. (2020).

\section{Kualitas Oosit}

Kualitas oosit yang dihasilkan pada waktu penyimpanan P1, P2, dan P3 secara berturut-turut dengan morfologi grade $\mathrm{A}=$ $13,2 \% ; 21 \% ; 7,6 \%$, grade $\mathrm{B}=73 \% ; 53,5 \%$; $47,8 \%$, grade $\mathrm{C}=7,8 \% ; 14,5 \% ; 22,9 \%$, dan grade $\mathrm{D}=6 \% ; 11 \% ; 21,6 \%$. Kualitas oosit 
Tabel 1. Kuantitas dan Kualitas Oosit

\begin{tabular}{lccccc}
\hline \multirow{2}{*}{$\begin{array}{l}\text { Waktu Penyimpanan } \\
\text { Ovarium }\end{array}$} & \multirow{2}{*}{ Kuantitas oosit } & \multicolumn{4}{c}{ Kualitas Oosit } \\
\cline { 3 - 6 } & & $\mathrm{A}$ & $\mathrm{B}$ & $\mathrm{C}$ & $\mathrm{D}$ \\
\hline 3 jam & 463 & $61^{\mathrm{A}}$ & $338^{\mathrm{A}}$ & $36^{\mathrm{A}}$ & $28^{\mathrm{A}}$ \\
& & $13,2 \%$ & $73,0^{\circ} \%$ & $7,8 \%$ & $6,0 \%$ \\
6 jam & 456 & $96^{\mathrm{B}}$ & $244^{\mathrm{B}}$ & $66^{\mathrm{B}}$ & $50^{\mathrm{B}}$ \\
& & $21,0 \%$ & $53,5^{\circ} \%$ & $14,5 \%$ & $11,0 \%$ \\
9 jam & 449 & $34^{\mathrm{C}}$ & $215^{\mathrm{C}}$ & $103^{\mathrm{C}}$ & $97^{\mathrm{C}}$ \\
& & $7,6 \%$ & $47,9 \%$ & $22,9 \%$ & $21,6 \%$ \\
\hline
\end{tabular}

Keterangan: Superscript yang berbeda pada kolom yang sama menunjukkan perbedaan yang sangat nyata $(\mathrm{P}<0,01)$

yang dapat digunakan untuk proses maturasi secara in vitro adalah oosit dengan morfologi grade $\mathrm{A}$ dan grade $\mathrm{B}$.

Persentase kualitas oosit yang dapat dimaturasi tertinggi adalah pada penyimpanan ovarium selama 3 jam (Tabel 1). Hal ini menunjukkan bahwa semakin cepat koleksi oosit dilaboratorium semakin baik pula kualitas oosit yang didapatkan. Hasil penelitian ini juga didukung oleh hasil penelitian Saleh (2017) yang menyimpulkan bahwa semakin cepat proses pengerjaan koleksi oosit di laboratorium maka semakin baik pula kualitas oosit yang didapatkan. Dimana kualitas ovarium dengan lama penyimpanan 2 jam dengan persentase sebesar $75 \%$ memberikan hasil lebih baik dibandingkan dengan lama penyimpanan 6 jam dengan persentase $68 \%$, 12 jam dengan persentase $61 \%$ dan 24 jam dengan persentase sebesar $55 \%$.

Kualitas oosit ditentukan oleh keberadaan sel kumulus. Peranan sel kumulus ini berhubungan dengan mekanisme gap junction, pengatur regulasi sinyal yang berkaitan dengan hormon dan kemampuan metabolisme oosit. Budiyanto et al. (2013) melaporkan bahwa lamanya waktu penyimpanan ovarium selama transportasi akan menyebabkan terjadinya kekurangan suplai darah ke ovarium akibat dari ovarium sudah terpisah dari tubuh ternak. Sehingga ovarium akan mengalami kondisi ischemia dan reoksigenasi. Kondisi ini ditandai dengan terhentinya supplai oksigen dan energi menuju ovarium. Menurut Febretrisiana dan Pamungkas (2017) melaporkan bahwa kondisi kekurangan oksigen ini akan mengakibatkan perubahan metabolisme aerob menjadi anaerob yang akan menghasilkan produk akhir berupa asam laktat. Perubahan metabolisme ini juga mengakibatkan terjadinya penurunan ATP. Akibat dari penurunan ATP ini adalah pengikatan antara phospat anorganik dengan $\mathrm{H}_{2} \mathrm{O}$ menjadi asam phospat. Akumulasi dari asam laktat dan asam phospat ini akan menyebabkan penurunan $\mathrm{pH}$ folikuler yang mengakibatkan oosit mengalami fragmentasi (Karaszewski et al., 2009)

Sumarmin (2005) melaporkan bahwa akibat dari penurunan $\mathrm{pH}$ folikuler ini adalah kerusakan pada lapisan epitel, dimana hubungan antar sel pada korteks dan medulla ovarium mulai berdegenerasi yang mengakibatkan jarak antar sel semakin melebar. Akibat dari degenerasi ini adalah menurunnya kepadatan tingkat seluler dan sel granulosa menjadi tidak teratur. Sel granulosa ini berperan dalam menyediakan substrat energi, beberapa asam amino, nukleotida dan prekusor fosfolipid ke oosit yang menghasilkan beberapa interaksi sinyal yang mempengaruhi inti sel dan sintesis protein stuktural. Degenerasi protein ini akan mengakibatkan oosit mengalami apoptosis.

\section{Tingkat Maturasi Oosit secara In Vitro}

Tingkat maturasi oosit selama waktu penyimpanan ovarium $\mathrm{P} 1, \mathrm{P} 2$, dan $\mathrm{P} 3$ secara bertutur turut pada status inti $\mathrm{GV}=22,1 \%$; 
JPI Vol. 22 (3): 346-352

Tabel 2. Tingkat Maturasi Oosit secara In Vitro

\begin{tabular}{cccccccc}
\hline \multirow{2}{*}{$\begin{array}{c}\text { Waktu } \\
\text { Penyimpan } \\
\text { Ovarium }\end{array}$} & \multirow{2}{*}{$\begin{array}{c}\text { Jumlah } \\
\text { ovarium }\end{array}$} & $\begin{array}{c}\text { Jumlah oosit } \\
\text { dimaturasi }\end{array}$ & GV & GVBD & M1 & A/T & M2 \\
\cline { 5 - 8 } 3 jam & 30 & $399^{\mathrm{a}}$ & $88^{\mathrm{A}}$ & $35^{\mathrm{A}}$ & $7^{\mathrm{A}}$ & $0^{\mathrm{a}}$ & $269^{\mathrm{a}}$ \\
& & & $22,1 \%$ & $8,7 \%$ & $1,7 \%$ & $0,0 \%$ & $67,4 \%$ \\
6 jam & \multirow{2}{*}{30} & $340^{\mathrm{ab}}$ & $42^{\mathrm{B}}$ & $54^{\mathrm{B}}$ & $39^{\mathrm{B}}$ & $1^{\mathrm{a}}$ & $204^{\mathrm{b}}$ \\
& & & $12,3 \%$ & $15,9 \%$ & $11,5 \%$ & $0,3 \%$ & $60,0 \%$ \\
\multirow{2}{*}{9 jam } & \multirow{2}{*}{30} & $249^{\mathrm{b}}$ & $66^{\mathrm{A}}$ & $53^{\mathrm{B}}$ & $26^{\mathrm{B}}$ & $0^{\mathrm{a}}$ & $104^{\mathrm{C}}$ \\
& & & $26,5 \%$ & $21,3 \%$ & $10,4 \%$ & $0,0 \%$ & $41,8 \%$ \\
\hline
\end{tabular}

Keterangan: Superscript dengan huruf besar yang berbeda pada kolom yang sama menunjukkan perbedaan yang sangat nyata $(\mathrm{P}<0,01)$ dan superscript dengan huruf yang kecil menunjukkan perbedaan yang nyata $(\mathrm{P}<0,05)$

$12,3 \% ; 26,5 \%, \mathrm{GVBD}=8,7 \% ; 15,9 \% ; 21,3 \%$, $\mathrm{M} 1=1,7 \% ; 11,5 \% ; 10,4 \%, \mathrm{~A} / \mathrm{T}=0 \% ; 0,3 \%$; $0 \%$, dan M2 $=67,4 \% ; 60 \% ; 41,8 \%$.

Proses pematangan inti sel berhubungan dengan aktivitas sintesis RNA. Oosit dikatakan telah mengalami pematangan apabila berada pada status inti sel tahap M2 yang ditandai dengan terbentuknya Polar Body 1 (Adelia et al., 2017). Widyastuti et al (2017) melaporkan bahwa oosit yang berada pada tahap M2 merupakan sel yang telah siap untuk dilakukan fertilisasi. Hasil penelitian menunjukkan bahwa waktu transportasi ovarium selama 3 jam memberikan persentase tingkat maturasi oosit mencapai M2 paling tinggi dibandingkan dengan waktu transportasi selama 6 jam dan 9 jam. Hal ini menunjukkan bahwa semakin lama ovarium dikoleksi di laboratorium, maka semakin sedikit pula oosit yang akan mengalami pematangan secara in vitro. Hasil penelitian ini juga didukung oleh hasil penelitian Febretrisiana et al. (2015) yang melaporkan bahwa lama waktu transportasi ovarium selama 2-4 jam memberikan persentase tingkat maturasi mencapai M2 tertinggi yaitu sebesar 70,83\% dibandingkan dengan waktu transportasi 5-7 jam sebesar $64,58 \%$ dan waktu transportasi 8-9 jam sebesar 7,84\%, sedangkan tingkat maturasi dengan status inti GV lama waktu transportasi 8-9 jam sebesar $39,21 \%$ memberikan persentase tertinggi dibandingkan dengan waktu transportasi 2-4 jam sebesar 2,08\% dan 5-7 jam sebesar $2,08 \%$.

Menurunnya kemampuan oosit mencapai M2 disebabkan karena kondisi ischemia dan re-oxsigenation selama waktu transportasi ovarium (Febretrisiana et al., 2015). Kondisi re-oxigenation ini akan menghasilkan oksigen bebas radikal yang bersifat toxic seperti superoxide anion $\left(\mathrm{O}^{-}\right)$, toxic hydroxylradicals $\left(\mathrm{OH}^{-}\right)$, dan hydrogen peroxide $\left(\mathrm{H}_{2} \mathrm{O}_{2}\right)$ yang akan bereaksi dengan protein, lipid, DNA menghasilkan inaktivasi enzim, peroksidasi membrane lipid, dan perubahan DNA (Catala, 2009). Selain itu kondisi ischemia ini akan mengakibatkan terjadinya penurunan $\mathrm{pH}$ folikel sebagai akibat dari asidosis asam laktat (Wongsrikeao et al., 2005). Asidosis asam laktat ini akan memproduksi ROS (reactive oxygen spesies) dimana akan mengakibatkan kerusakan pada mitokondria DNA, protein, lipid, berkurangnya ATP, peningkatan $\mathrm{Ca}^{+}$cystolic, dimana semua parameter tersebut berperan dalam menentukan dinamika keseimbangan mikrotubulus dan mikrofilamen. Jika keseimbangan mikrotubulus dan mikrofilamen terganggu maka akan memicu terjadinya kelainan pada sitoskleton. Salah satu akibat dari kelainan sitoskleton ini adalah terhambatnya ekstruksi polar body 1 sehingga oosit akan terhenti membelah mencapai M2. 


\section{KESIMPULAN}

Dari hasil penelitian yang telah dilakukan dapat disimpulkan bahwa kuantitas dan kualitas oosit serta tingkat matutasi oosit secara in vitro pada waktu penyimpanan ovarium selama 3 jam memberikan hasil terbaik dibandingkan dengan waktu penyimpanan selama 6 jam dan 9 jam.

\section{DAFTAR PUSTAKA}

Adelia, R., N. W. K. Karja. dan M. A. Setiadi. 2017. Kafein dalam medium maturasi meningkatkan fertilisasi dan menekan frekuensi polispermi oosit domba dengan maturasi diperpanjang. J. Veteriner. 18(3): 337-344

Badan Pusat Statistik. 2019. Angka pemotongan sapi di Indonesia. http:// www.bps.go.id. (20 September 2019).

Budiyanto, A., S. Gustari., D. Anggoro., D. Jatmoko., S. Nugraheni., E. W. Nugraha, dan D. Asta. 2013. Kualitas morfologi oosit sapi peranakan ongole yang dikoleksi secara in vitro menggunakan variasi waktu transportasi. ACTA Veterinaria Indonesia. 1(1): 15-19

Catala, A. 2009. Lipid peroxidation of membrane phospholipids generates hydroxy-alkenals and oxidized phospholipids active in physiological and/or pathological conditions. Chemistry and Physics of Lipids. 157: $1-11$.

Direktorat Jendral Peternakan dan Kesehatan Hewan Kementrian Pertanian. 2018. Pengendalian Pemotongan Betina Produktif UPSUS SIWAB.

El-Raey, M. and T. Nagai. 2014. Different Aspects of Cattle Oocyte in vitro Maturation: Review. J. Reprod and Infertility. 5(1): 01-13.

Febretrisiana dan F. A. Pamungkas. 2017. Pemanfaatan ovarium yang berasal dari rumah potong hewan sebagai sumber materi geenetic. Wartazoa. 27(4): 159166.

Febretrisiana., M. A. Setiadi, and N. W. K. Karja. 2015. Nuclear maturation rate of sheep oocyte in vitro: Effect of storage duration and ovary temperature. $\mathrm{J}$ Indonesian Trop Anim Agric. 40: 9399.

Gordon, I. 2003. Laboratory production of cattle embryos. $2^{\text {nd }}$ edition. Willingford UK: CABI. Publishing.

Hendri., Z. Udin, dan Jaswandi. 2004. Bioteknologi Reproduksi Ternak. Universitas Andalas.

Ikhwan, N., N. S. D. Solihati., Rasad, dan R. Widyastuti. 2016. Perubahan ukuran folikel ovarium dan kualitas oosit pada ovarium domba lokal pasca preservasi dengan waktu yang berbeda. Jurnal Ilmu Ternak. 16(1): 36-41

Karaszewski, B., J. M. Wardlaw., I. Marshall., V. Cvoro., K. Wartdowska., K. Haga., P. A. Armitage., M. E. Bastin, and M. S. Dennis. 2009. Early brain temperature elle vation and anerobic metabolism in human acute ischemic stroke. Brain. 132: 955-964.

Saleh. 2017. Assessment of different methods of bovine oocytes collection, maturation and in vitro fertilization of abattoir specimens. Iraqi Journal of Veterinary Sciences. 31(1): 55-56.

Sumarmin, R., T. L. Yusuf., A. Winarto, and A. Boediono. 2005. Histologi ovarium domba pasca transplantasi intrauterin pada kelinci pseudopregnansi. Animal Production. 10(2): 17 - 84.

Vicanco and H. W. Mackie. 2001. Embrio transfer in ovine and caprine. Biotecnology of reproduction. Palma $\mathrm{G}$, editor. AGT Ediciones Inta.

Widyastuti, R., M. R. A. A. Syamsunarno, T. Saili, and A. Boediono. 2017. Oocyte quality and subsequent in vitro maturation of sheep oocyte cumulus complex from ovary with presence and 
JPI Vol. 22 (3): 346-352

absence of corpus luteum. Proceedings of The Veterinary Medicine International Conference. Surabaya: 166-174.

Wongsikreo. 2005. Effect of ovary stroge time and temperature on DNA fragmentation and development of porcine oocyte. J. Repro and Dev. 51: 87-97.
Udin, Z., Masrizal., Hendri, and S. Nanda. 2020. Evaluation of different techniques in recovering of oocyte and storage duration of ovaries on the quality and quantity of bovine in vitro maturation. Bulletin of Animal Science. 44(2): 1-7. 